findings of the research have shown that a possible manifestation of a dysfunction of the hepatobiliary system in children from an ecologically unfavourable region is the onset of the biochemical signs of the syndrome of cholestasis.

Key words: children, ecologically-conditioned pathology, hepatobiliary pathology, ecologically unfavourable region.

SI “The Institute of Hereditary Pathology of Ukraine's NAMS” (Lviv)

Рецензент - проф. Т.В. Сорокман

Buk. Med. Herald. - 2013. - Vol. 17, № 2 (66). - P. 80-83

Надійшла до редакції 21.03.2013 року

(c) М.В. Лучак, О.З. Гнатейко, Н.С. Лук'яненко, С.О. Печеник, 2013

УДК 616.127-008.1:616-12-009.72-008.6

\title{
I.В. Малишевська
}

\section{ОСОБЛИВОСТІ ФУНКЦІОНАЛЬНОГО СТАНУ МІОКАРДА У ПАЦІЕНТІВ ЗІ СТАБІЛЬНОЮ СТЕНОКАРДІЕЮ, ПОСДНАНОЮ 3 МЕТАБОЛІЧНИМ СИНДРОМОМ}

Буковинський державний медичний університет, м. Чернівці

Резюме. У статті представлені результати аналізу впливу наявності метаболічного синдрому (МC) на міокардіальну дисфункцію. Встановлено більш виражені ознаки ремоделювання лівого шлуночка (ЛШ) у хворих $з$ комбінацією стабільної стенокардії (СС) та метаболічного синдромому (МС) незалежно від стану глобальної скоротливості ЛШ. Нами не виявлено кореляцій-

Вступ. Відомо, що найбільш ранньою ознакою ураження міокарда при цукровому діабеті (ЦД) $є$ поява дисфункції діастоли з подовженням релаксації діастоли 3 подальшим приєднанням дилатації порожнини лівого шлуночка і розвитком прогресуючої серцевої недостатності (застійна кардіоміопатія), порушень серцевого ритму. Дослідження, проведені в пацієнтів із цукровим діабетом (ЦД) показали, що для діабетичного серця характерний фіброз міокарда, який може бути пов'язаний із порушенням внутрішньоклітинного метаболізму NO і кальцію, а також 3 проліферативними процесами, зумовленими дією інсуліну та інсуліноподібного фактору росту $[6,11]$. Такі чинники ризику, як АГ і дисліпідемія, прискорюють розвиток або сприяють прогресуванню діабетичної кардіоміопатії [3, 4]. Приєднання ішемічної хвороби серця (IXC) ускладнює ії течію.

Мета дослідження. Провести порівняльний аналіз стану систолічної та діастолічної функції в пацієнтів зі стабільною стенокардією (СС), яка проходила ізольовано та на тлі МС.

Матеріал і методи. Нами обстежено 137 пацієнтів із СC (79 (57,7\%) чоловіків та 58 (42,3 \%) жінок). Середній вік пацієнтів становив $56,2 \pm 0,8$ року (від 34 до 75 років). Обстежені пацієнти в цілому по групі характеризувалися тривалістю попередньої історії IXC у середньому $38,4 \pm 3,8$ місяця.

Основну группу склали 107 (78,1 \%) хворих на СC із супутнім МC, контрольну - 30 (21,9\%)

(C) І.В. Малишевська, 2013 ного зв'язку між показниками внутрішньосерцевої гемодинаміки та маркерами атеросклеротичного процесу, a саме рівнем загального холестерину (3ХC) та среактивного протеїну (СРП).

Ключові слова: стабільна стенокардія, метаболічний синдром, ехокардіографія.

пацієнтів зі СС. Критерій включення в основну групу: наявність супутнього МС. Для постановки діагнозу МС використовували критерії відповідно до рекомендацій Міжнародної федерації з вивчення цукрового діабету (2007р.).

У ході дослідження пацієнтам проведено обстеження, яке включало аналіз клінічних варіантів патології, що вивчалася, зокрема аналіз скарг, анамнезу життя та захворювання, клінічнолабораторні дослідження 3 аналізом загального аналізу крові, ліпідограми, С-реактивного протеїну (СРП), що визначали імуноферментним методом у 1-шу добу та через один місяць після лікування. Оцінка динамічних змін ЕКГ, проведення ехокардіологічного (ЕхоКГ) дослідження у двох режимах (М-таВ-) на 1-шу добу находження до стаціонару та через один місяць після лікування.

Результати дослідження та їх обговорення. Аналіз основних показників ЕхоКГ дослідження показав, що у хворих на IXC та МC порівняно $з$ пацієнтами без МС реєструвалися наступні зміни показників: поперечний розмір лівого передсердя (ЛП) вірогідно більший у пацієнтів з $\mathrm{MC}(4,03 \pm 0,05$ проти $3,69 \pm 0,04, p<0,01)$, показники кінцевого діастолічного об'єму (КДО) та показники кінцевого систолічного об’єму (КСО) також були більшими в пацієнтів основної групи, причому різниця була вірогідна (КДО: 139,51 $\pm 3,21$ мл проти 130,26 $\pm 2,92$ мл, p<0,05;

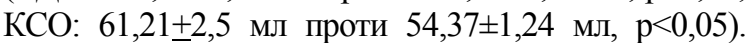
Показник ступеня гіпертрофії ЛШ, за даними товщини стінок та індексу маси міокарда (IMM) ЛШ, також був достовірно більшим у пацієнтів із 
Таблиця 1

Зіставлення показників ехокардіографії у М-режимі в основній та контрольній групах на початку лікування

\begin{tabular}{|c|c|c|c|c|c|}
\hline & \multicolumn{2}{|c|}{ Основна група } & \multicolumn{2}{|c|}{ Контрольна група } & \multirow{2}{*}{$\mathrm{p}$} \\
\hline & M & $\mathrm{m}$ & M & $\mathrm{m}$ & \\
\hline ЛПс, см & 4,03 & 0,05 & 3,69 & 0,04 & $\mathrm{p}<0,01$ \\
\hline КДО, мл & 139,51 & 3,21 & 130,26 & 2,92 & $\mathrm{p}<0,05$ \\
\hline КСО, мл & 61,21 & 2,5 & 54,37 & 1,24 & $\mathrm{p}<0,05$ \\
\hline 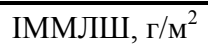 & 126,41 & 3,11 & 100,93 & 2,98 & $\mathrm{p}<0,01$ \\
\hline ЗФВ, \% & 52,34 & 2,28 & 55,53 & 2,43 & $\mathrm{p}<0,05$ \\
\hline
\end{tabular}

Таблиця 2

Кореляція функцій викиду лівого шлуночка (\%) з маркерами атеросклеротичного процесу у хворих на стабільну стенокардію

\begin{tabular}{|c|c|c|c|}
\hline Показник & $\begin{array}{c}\text { СС та MC } \\
\mathrm{M} \pm \mathrm{SD}\end{array}$ & $\begin{array}{c}\text { СС без MC } \\
\mathrm{M} \pm \text { SD }\end{array}$ \\
\hline СРП, у.о. & $\mathrm{r}=0,11$ & $\mathrm{r}=0,24$ & $\mathrm{p}<0,05$ \\
\hline ЗХС, ммоль/л & $\mathrm{r}=0,13$ & $\mathrm{r}=0,27$ & $\mathrm{p}<0,05$ \\
\hline
\end{tabular}

Таблиця 3

Кореляція функцій викиду лівого шлуночка (\%) з маркерами атеросклеротичного процесу у хворих на стабільну стенокардію

\begin{tabular}{|c|c|c|c|}
\hline Показник & $\begin{array}{c}\text { СС та MC } \\
\mathrm{M} \pm \mathrm{SD}\end{array}$ & $\begin{array}{c}\text { СС без MC } \\
\mathrm{M} \pm \mathrm{SD}\end{array}$ \\
\hline СРП, у.о. & $\mathrm{r}=0,11$ & $\mathrm{r}=0,24$ & $\mathrm{p} 0,05$ \\
\hline ЗХС, ммоль/л & $\mathrm{r}=0,13$ & $\mathrm{r}=0,27$ & $\mathrm{p} 0,05$ \\
\hline
\end{tabular}

$\begin{gathered}\text { ексцентрична } \\ \text { гіпертрофія } \\ 14,02 \%\end{gathered}$
нормальна
геометрія ЛШ

концентрична гіпертрофія

$59,81 \%$

Рис. Розподіл пацієнтів основної групи залежно від результату ЕхоКГ

супутнім МC $(126,41 \pm 3,11$ проти $100,93 \pm 2,98$, $\mathrm{p}<0,01)$. Разом із тим не виявлено достовірної різниці в основній групі та групі контролю в оцінці глобальної скоротливості ЛШ, за даними ФВ ЛШ $(52,34 \pm 2,28 \%$ проти $55,53 \pm 2,43 \%, \mathrm{p}<0,05)$. Отримані нами дані свідчать про більш виражене ремоделювання ЛШ у пацієнтів із комбінацією СС та МС незалежно від стану глобальної скоротливості ЛШ (табл. 1).

На наступному етапі дослідження нами оцінювалася наявність того чи іншого типу гіпертрофії ЛШ у пацієнтів основної групи, оскільки всі вони мали супутню АГ. Залежно від результатів ЕхоКГ дослідження пацієнтів із СС поєднаною з МС розподіленими на три групи: до I групи увійшли 28 (26,17\%) осіб з нормальною геометрією ЛШ (відносна товщина стінки ЛШ

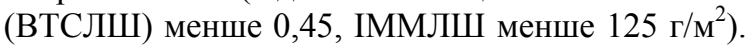
До II групи включено 64 (59,81 \%) пацієнти, у яких при ЕхоКГ виявлено концентричну гіпертрофію ЛШ (ВТСЛШ більше 0,45, ІММЛШ біль-

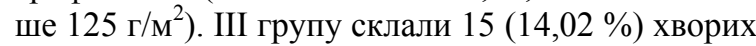
на $\mathrm{CC}$, у яких поряд із гіпертрофією міокарда відмічалася дилатація порожнини ЛШ, тобто виявлено ексцентричну гіпертрофію ЛШ (ВТСЛШ

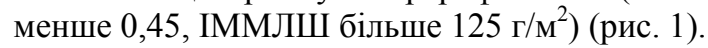

Отже, в основній групі вірогідно більш виражені ознаки ремоделювання серця та гірші показники діастолічної дисфункції та переднавантаження ЛШ, такі, як розмір ЛП, що свідчить про більш виражене загальне порушення міокардіальної функції при комбінації СС та МС. Враховуючи наявність АГ у $100 \%$ досліджених хворих основної групи, наявність діастолічної дисфункції в них $є$ припустимою навіть за відсутності коронарних подій в анамнезі.

3 джерел літератури відомо $[1,10]$, що у хворих на Цд 2-го типу у віці 40-70 років, як і в осіб 
iз порушеною толерантністю до вуглеводів, виявляють значне підвищення числа лейкоцитів, концентрації С-реактивного білка і фібриногена в сироватці крові порівняно з контрольною групою незалежно від статі і віку хворих.

Викликаючи агрегацію частинок ліпопротеїдів дуже низької та низької щільності в атеромі, СРП полегшує їх захоплення макрофагами. Таким чином, можна припустити, що СРП відіграє провідну роль у розвитку негативних ефектів при судинному запаленні, викликаючи не тільки ініціацію і прогрес, але і дестабілізацію атероми [2, 9]. Таким чином, рівень СРП разом із рівнем загального холестерину (3X) можна розцінювати як маркер активності атеросклеротичного процесу.

Нас зацікавило виявлення наявності чи відсутності кореляційного зв'язку між показниками внутрішньосерцевої гемодинаміки та маркерами атеросклеротичного процесу, а саме рівнем $3 \mathrm{X}$ та СРП. Проведений аналіз вказував на відсутність кореляційного зв'язку як в основній групі, так і в групі контролю між досліджуваними показниками (табл. 3).

Отримані нами дані знаходять підтвердження в роботах інших дослідників, які відмічають, що ступінь погіршення показників систолічної функції та навантаження ЛШ прямо залежить від ступеня ураження власне серцевого м'яза, та не може прямо свідчити про характер метаболічних змін та стан судин внаслідок атеросклерозу [5, 12].

Вирішальним фактором зменшення коронарного дилатаційного наповнення в пацієнтів з IXC та MC за відсутності стенозу відповідної коронарної артерії є структурна перебудова інтраміокардіальних коронарних артерій та накопичення колагену. Фактор підвищеного ризику в популяції з більш тяжкою гіпертензією можна пов'язати зі зменшенням коронарного резерву при IXC та MC $[7,8]$.

\section{Висновок}

Таким чином, можна дійти висновку, що хоча значення інтегрального показника скоротливості лівого шлуночка не $\epsilon$ прямо пов'язаним 3 маркерами системного атеросклеротичного процесу, наявність супутнього метаболічного синдрому у хворих на стабільну стенокардію прискорює прогресування ремоделювання лівого шлуночка та поглиблює міокардіальну дисфункцію лівого шлуночка.
Перспективи подальших досліджень. Результати проведеної роботи вказують на більш виражене загальне порушення міокардіальної функції при комбінації СС та МС, доцільним вбачається вивчення стану коронарного резерву в обраної категорії хворих із подальшим пошуком шляхів оптимізації тактики лікування.

\section{Література}

1. Аметов А.С. Сердечно-сосудистое ремоделирование в условиях инсулинорезистентности, органопротективные возможности патогенентически обоснованной терапии / А.С. Аметов, Т.Ю. Демидова, Л.В. Смагина // Сердце. - 2004. - Т. 3, № 6. - С. 312-315.

2. Коваленко В.М. Харчування i хвороби системи кровообігу: соціальні і медичні проблеми / В.М. Коваленко // Нов. мед.: метаболічний синдром. - 2004. № 3 (14). - С. 12-16.

3. Лишневская В.Ю. Метаболический синдром в клинике врача общей практики / В.Ю. Лишневская // Кровообіг та гомеостаз. - 2005. - № 2. - С. 18-28.

4. Маньковський Б.Н. Метаболічний синдром: розповсюдженість, діагностика, принципи терапії / Б.Н. Маньковський // Мистецтво лікування. - 2005. № 9. - C. 30-33.

5. Мітченко О.І. Патогенетичні основи метаболічного синдрому / O.I. Мітченко // Нов. мед.: метаболічний синдром. - 2004. - № 3(14). - С. 20-24.

6. Передерий В.М. Ожирение: междисциплинарный вызов XXI века / В.М. Передерий // Здоров'я України. - 2010. - № 10 (239). - С. 22-23.

7. Bakhshaliev A.B. Comparison of the effectiveness of moxonidine and prestarium in postmenopausal women with mild and moderate arterial hypertension / A.B. Bakhshaliev, G.M. Sabzalieva // Klin. Med. (Mosk). - 2006. Vol. 84 (4). - P. 41-44.

8. Fisman E.Z. Systemic hypertension in postmenopausal women: a clinical approach / E.Z. Fisman, A. Tenenbaum, A. Pines // Curr. Hypertens. Rep. - 2002. - Vol. 4. P. 464-470.

9. Johnston and S. Yusuf // Eur. Heart J. - 2002. - Vol. 23. P. 1771-1779.

10. Leptin and the proinflammatory state associated with human obesity / C.J. Hukshorn, J.H. Lindeman, K.H. Toet [et al.] // J. Clin. Endocrinol. Metab. - 2004. - Vol. 89. P. 1773-1778.

11. Effects of obesity, body composition, and adiponectin on carotid intima-media thickness in healthy women / J. Lo, S.E. Dolan, L.C. Kanter [et al.] // J. Clin. Endocrinol. Metab. - 2006. - Vol. 91. - P. 1677-1682.

12. The paraoxonase gene family and atherosclerosis / C.J. Ng, D.M. Shih, S.Y. Hama [et al.] // Free Radic. Biol. Med. - 2005. - Vol. 38. - P. 153-163.

\section{ОСОБЕННОСТИ ФУНКЦИОНАЛЬНОГО СОСТОЯНИЯ МИОКАРДА У ПАЦИЕНТОВ СО СТАБИЛЬНОЙ СТЕНОКАРДИЕЙ, СОВМЕЩЕННОЙ С МЕТАБОЛИЧЕСКИМ СИНДРОМОМ}

\section{И.В. Малишевская}

Резюме. В статье представлены результаты анализа влияния наличия метаболического синдрома (МС) на миокардиальную дисфункцию. Установлено более выраженные признаки ремоделирования левого желудочка (ЛЖ) у больных с комбинацией стабильной стенокардии (СС) и метаболического синдрома (МC) независимо от состояния глобальной сократимости ЛЖ. Нами не выявлено корреляционной связи между показателями внутрисердечной гемодинамики и маркерами атеросклеротического процесса, а именно уровнем общего холестерина (OXC) и среактивного протеина (СРП).

Ключевые слова: стабильная стенокардия, метаболический синдром, эхокардиография. 


\section{SPECIFIC CHARACTERISTICS OF THE FUNCTIONAL STATE OF THE MYOCARDIUM IN PATIENTS WITH STABLE ANGINA PECTORIS COMBINED WITH THE METABOLIC SYNDROME}

\section{I.V. Malyshevs'ka}

Abstract. The paper presents the results of an analysis of the influence of the presence of the metabolic syndrome (MS) on the myocardial dysfunction. More marked signs of a remodelling of the left ventricle (LV) have been established in patients with a combination of stable angina (SA) and MS, irrespective of the state of the global contractility of the LV. We haven't detected a correlation between the indices of the intracardiac hemodynamics and the markers of the atherosclerotic process, namely, the level of total cholesterol (TCS) and C-reactive protein (CRP).

Key words: stable angina pectoris, metabolic syndrome, echocardiography.

Bukovinian State Medical University (Chernivtsi)

Рецензент - проф. О.С. Полянська
Buk. Med. Herald. - 2013. - Vol. 17, № 2 (66). - P. 83-86

Надійшла до редакції 16.05.2013 року

(C) І.В. Малишевська, 2013

УДК 616.72-007.24:[612.398:577.12+612.017

О.П. Микитюк

\section{ДОБОВА ТА СЕЗОННА ХАРАКТЕРИСТИКА ПРОЦЕСІВ ВІЛЬНОРАДИКАЛЬНОЇ МОДИФІКАЦІЇ МАКРОМОЛЕКУЛ ТА АНТИОКСИДАНТНОГО ЗАХИСТУ У ХВОРИХ НА ОСТЕОАРТРОЗ}

Буковинський державний медичний університет, м. Чернівці

Резюме. Проведено порівняння добової та сезонної організації вмісту в крові продуктів вільнорадикальної модифікації макромолекул та активності факторів антиоксидантного захисту в крові хворих на остеоартроз. Показано, що остеоартроз супроводжується пору-

Вступ. Більшість функцій організму характеризується циклічністю вродовж певних часових проміжків та узгодженістю цих коливань [1]. Найбільшу увагу приділяють вивченню добових та сезонних ритмів, оскільки вони регулюються чітко описаними факторами. Часова дезорганізація (десинхроноз) біологічних функцій $є$ ключем фізіологічного процесу старіння і патогенезу захворювань, оскільки полягає в порушенні зворотного зв'язку регуляції. Вона трапляється при перебуванні організму в екстремальних для нього умовах, за впливу патогенних чинників, та іноді - у перехідні фази річного циклу (весна та осінь) [2].

Ритмічність етіологічних факторів і часова організація органів-мішеней зумовлює варіабельність суб' єктивних та об'єктивних клінічних проявів захворювань. Існування добових варіацій клінічно-лабораторних параметрів у хворих на остеоартроз (ОА) - патологію опорно-рухового апарату, підтверджене неодноразово. Проте при плануванні більшості досліджень та діагностичних процедур добова динаміка біохімічних показників враховується не завжди.

Мета дослідження. Аналіз добової динаміки та міжсезонних відмінностей вмісту в крові продуктів вільнорадикальної модифікації макромо- шенням як добової, так і сезонної організації вмісту в організмі досліджуваних показників.

Ключові слова: остеоартроз, добові ритми, сезонні ритми, вільнорадикальні процеси, антиоксиданти. захисту у хворих на остеоартроз.

Матеріал і методи. Для вирішення задач дослідження обстежено 88 хворих на ОА, що перебували на стаціонарному лікуванні в ревматологічному відділенні міської лікарні № 3 м.Чернівці. Співвідношення „жінки:чоловіки”

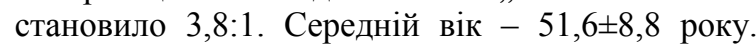
Тривалість захворювання склала $8,4 \pm 4,6$ року. Діагноз ОА встановлювали на основі уніфікованих критеріїв, розроблених Американською Ревматологічною Асоціацією.

У всіх пацієнтів отримано згоду на участь у дослідженні відповідно до вимог Належної Клінічної Практики. Всі процедури відповідали стандартам Гельсінської декларації 1975 р. та їі перегляду 1983 р.

Для характеристики добових та сезонних особливостей клінічної картини у хворих на ОА проводили посезонний розподіл обстежених пацієнтів (обстежено 20 пацієнтів - узимку, 28 навесні, 20 - влітку та 20 - в осінні місяці). Контрольні обстеження виконані в групі практично здорових осіб $(\mathrm{n}=42)$, у яких на час обстеження не було загострень хронічної патології органів дихання чи травного каналу, серцево-судинної системи, а та- 